\title{
THE EVOLUTION OF A WHITE'S BLACK CONSCIOUSNESS
}

\author{
SUZANNE W. JAWORSKI \\ School of Public Health \\ University of Michigan
}

In 1964, I was a college sophomore living in downtown Tampa, Florida. Every morning at 7 a.m. I caught a bus which got me to the University of South Florida in an hour and a half. The bus was typically filled at this hour with black cleaning women going out to the Tampa suburbs. I met my first black friend, a maid named Zeena, on this bus. I say "black" now -at that time in my life I probably would have said "nigra"-the white middle-class Southerner's way of showing he is above using "nigger," but too damned good to grace those people with "Negro."

I got from nigra to black through a series of exposures and experiences, complex and still bewildering to me in some ways, that were sometimes sought and sometimes unsought. They define no more than the evolution of one individual's consciousness, for what it's worth. My experiences and my expression of them are personal and finite-in no way definitive or capable of extension to generalized truths. My urgency to express them comes not out of what I want to "do" for black people, but out of an appreciation of what black people have done for me. 
I was born and raised unequivocally Southern WASP. My parents were white Episcopalians of English-Scotch-Irish descent, both from Georgia. My father was a mechanic, my mother a housewife. Hovering in both of their backgrounds, however, were strains of a nostalgia for pre-working-class days. My father was from a family of Southern aristocrats; his great-grandfather had been a Confederate officer and descendant of New England Puritans. My mother came of a wealthy, though not so aristocratic, Coffee County gentleman farmers' tradition. Her father was a Ku Klux Klan member whose Negro farmhands existed in a situation evidently closer to plantation slavery than to tenant farming.

Despite this, my childhood memories of explicit racist training and consciousness are almost nil. I think non-Southerners assume that a Southern child grows up in an atmosphere where racial epithets and bitterness are an everyday diatribe, where a mixed diet of fear and hatred of blacks is daily served up with the cornbread. This results, I think, from the tendency of non-Southerners to characterize the South and Southerners only in terms of their racial stance, as if Southerners exist only when they are blocking school integration in Little Rock or following Lester Maddox, ax handle in hand, to defend his restaurant. The media and the drives for civil rights awareness in the sixties have enhanced this image.

In fact, the awareness of black people with which I grew up, although thorough-going in its assumptions of white superiority and in an insidious fostering of myths, was static, inarticulated. Nobody ever talked about black people, even negatively. Somehow I came to assimilate what most Southern white children do: there is a "colored section" of town; it's hard to get good help these days; the brother-in-law has to bail his garage workers out of jail most Saturday nights.

But the important thing about this consciousness was that it was in the background. Blacks rode in the back of our 
buses, all the kids in my school were white, there were white and colored drinking fountains in the downtown dime stores-in hundreds of ways, I was exposed to the relegated, segregated situation of black people. But 1 never had any reason to question this; it simply was the way it was.

My conscious memories of the role of black people and their relationship to us are so few that I think I can remember most of them.

When I was five, we were living on a defunct farm outside Macon, Georgia. I was not yet in school and in that beautiful free period of childhood when impressions are received through so few filters. I spent most of my day roaming the pine woods around the house alone. The woods I remember as dark and vast. I vaguely knew there were nigras in some parts of those woods; this greatly enhanced the mystery. I never knew exactly, but there was something fearful and highly challenging about sleeping on the screened front porch during the summer, and my brother was the only one deemed brave enough. This somehow connected in my mind with the nigras.

In Tampa during my grade school years, we occasionally had black women in to do ironing or delivered it to their houses in that other part of town. I remember them being either quiet or jovial, and my mother being solicitous that they had enough lunch or coffee. Nothing else.

Tampa's lower Central Avenue replaced the Georgia backwoods for me as the unknown habitat of black people. $I$ knew my mother was afraid to drive down Central Avenue, especially on Saturday night. But the few times we did, I remember being curious and thinking it interesting-especially the loud, blaring music from the bars. It must have been at this time that I came to associate knives with Negroes, but in that era before the paranoia over crime, this was fearsome only because the blacks used them on each other.

When I was twelve, we went to visit my sister in Atlanta. Two things about that city impressed me: the hills and the 
black people. Atlanta seemed mountainous after the flat streets of Tampa; and I was amazed to see well-dressed, good-looking black people. Some of them wore suits and looked like they might even be businessmen. I didn't know such a thing was possible! My assumptions heretofore were (1) all black people are fat and ugly; (2) all black people are poor. I saw beautiful, coiffured, stylish black people who walked with their heads up as if they were the same as us. This intrigued me, and I stared a lot. Tampa in the fifties didn't exactly abound with middle-class blacks. I didn't know that blacks could be other than cleaning women, construction workers, or kids on skates.

Childhood passed; there were "coon" jokes and nigger jokes, but no other reference to that other world. My senior year in high school I attended a conference on Latin America at Florida Presbyterian College in St. Petersburg. In my dormitory, there were girls from black high schools, but they were all put in one room. I didn't question the rightness of this, but I was a little disappointed that I couldn't get to know any of them. They were shy and giggly and seemed appreciative just to have been invited, but they were hesitant when I tried to start conversation. My real disappointment came at the dance that concluded the conference. I loved to dance, and was quick to see that the best dancers there were black boys. I wanted to dance with them. It was my turn to be shy and hover along the sidelines near their group, hoping one of them would ask me. They didn't.

I was seventeen at the time; society had arranged things in such a way that this late date represented the first time I had ever met or spoken with a black peer.

COLLEGE

Three things happened my freshman year in college that initiated the long evolution of my consciousness. Significantly, none of them issued out of my academic experience directly. It was 1962, and the South was well into the civil 
rights movement, but my University was virtually untouched. I graduated in 1966, and I don't remember a single professor or campus editorial espousing the movement all that time. There must have been a few, but there was certainly no widespread activity or discussion.

The first of these three things was a minor flare-up with my mother. We were standing in our driveway when an elderly black woman came up to me and asked me for directions. I gave them to her, and at several points in her questioning responded with "yes, mam." When she was gone, my mother gave me hell for addressing that black woman as mam. I had been taught, Southern fashion, to respond to my elders with "mam" or "sir"- no one had ever mentioned that this token of respect should be withheld from elders who were black. I was infuriated, and vented it. I was still unaware of blacks as a class, their political-social straits, and about a million other facets of life, but I had a sense of dignity in other people and of consistency in principles, and my mother's anger seemed petty to the point of viciousness.

For an education course that year, I wrote a paper on the "question" of black intelligence-whether it was innately inferior, conditioned, and so on. I found few research resources, and they stacked up about $60-40$ for innate inferiority. My professor gave me an $\mathrm{A}$ and added a few notes questioning my conclusions. That paper now seems remarkable to me, not so much in its conclusions, but in that I even chose the subject. A course such as "teaching in the inner city" did not exist in the education curriculum, even in remote facsimile. Teaching techniques and curriculum for minority, low-income, or urban children were nonexistent. Neither were there courses taking cognizance of black people anywhere else in the university-not in history, sociology, literature, or political science.

The last month of that freshman year I met a self-styled Socrates in the library. He took all eighteen years' worth of my beliefs, values, and mores, and turned them inside out. I 
served a three-week intellectual apprenticeship with him that probably affected me more than all four years of college classes put together. When I met him, I was a sorority girl, a "good" though docile student, and somewhat of a prude. We argued. He was extremely facile with language and logic, and all my "reasons" for segregation, it became apparent, couldn't hold water. I couldn't admit I was wrong, but gaining his respect became an incentive for listening, and the years of blockage were dented.

Through all the rest of college, there was little exposure or questioning about that black world and what it was like. Once in my junior year, the only black member of the university band (there were maybe five blacks in the university's then- 6,000 population) was refused service at a nearby restaurant. The university community-the staff as well as the faculty and students-organized a successful boycott. I was asked to picket. Sympathetic to the cause, but decidedly apolitical, I replied that I wasn't interested.

In a tough history course, I saw a professor single out a black's paper for an exercise in demolition. He used it to illustrate the epitome of what was not wanted in a paper. The conceptualization was poor, the language confused-he went on at great length while the student, the only black in the class, sat mute and humiliated. He dropped the class next day. With this incident, I got my first inkling of how complex and painful the black man's entry into our world was likely to be. The professor was so scholarly and myopic about the subject at hand that he couldn't take time to be sensitive about the human repercussions. I knew him well and am certain he selected the paper without even recognizing the name or putting it with a face. I couldn't, then or now, have condoned his overlooking poor scholarship. On the other hand, he set a performance criterion which was not predicated on where his students (white or black) were at. You either cut it, or you didn't; there was no consideration made of precollege background. In effect, this meant scholarship, 
not learning, was put foremost. So it was a race, and if, for whatever reason, you couldn't begin at those starting gates that had been designated, you didn't run.

A black guy named Pat was adopted by the "beatniks" of the school. (We were actually postbeatnik and prehippie and were generally referred to by the rest of the school as the Scrounge Lounge.) Everybody loved him, because the group needed a black to make it properly eclectic, but few people actually liked him. Unlike the few other blacks around, who were trudging, silent commuter types, Pat was obstreperous and loud. He had an obnoxious habit of insinuating himself into every conversation, but was tolerated by these white kids for being, after all, black. They were trying to love black, and he was their only chance for trying out this new emotion. He branded me a racist one night in a local coffeehouse when I told him I couldn't stand him, black or not.

These very limited experiences constituted my whole experience with blacks, except for Zeena. Zeena and I made semi-obscene jokes and hassled the bus driver. We got into giggling fits that sometimes landed us on the floor when the driver would turn a comer quickly in retaliation. I gave her some books because I noticed she read a lot, but never any thing above the quality of True Story.

Zeena was much realer to me than something called the Civil Rights Movement.

THE OEO

In 1967, I moved to Atlanta and started looking for a job that would be involving enough to take my mind off the personal losses and unhappinesses that had made me leave Tampa. I applied to the Office of Economic Opportunity's regional office there, knowing little more about the OEO than what the initials stood for.

I did a subtle double-take when I was introduced to the 
man who was to interview me-a young black man. By now I had intellectually accepted black equality, but I still didn't know any black people. He was a little dubious of me as a white Southerner, but when we got into Florida politics, we found we had a lot of outrage to share. I was hired to be a field representative and program analyst for the Florida Division of the Community Action Program.

The two years at OEO were incredibly rich, in large measure because of the newfound black world I entered. (By now I knew that black definitely was another world.) From point zero in black consciousness, I came into a professional and social life that was almost entirely based in the black community. My supervisor was black, my supervisor's supervisor was black, about half the regional staff was black. The community groups, consultants, advocacy organizations, CAP agency staffs-and the poor constituent population servedall were largely composed of black people. Soon, too, most of my friends and dates, the parties I attended, were black.

I will always think it an advantage that I entered this world with little knowledge of or proclivity toward social-political activism. I had no liberal credentials. I had never espoused causes. I didn't feel the burden of black liberation rested on my shoulders. I was drawn to the black world, not because I wanted to establish the credibility to be one of its saviors, but because it enticed me. I sensed there were things there-ways of looking at the world, styles, modes, images, languages $-\mathrm{a}$ kind of living I hadn't yet looked at. From my first day at OEO, when I wonderingly gaped at two young black men dancing (literally) up to a secretary's desk and giving her every line of jive at their disposal to get her to come to lunch with them, I was in trigued.

My first weeks there, I was constantly observing. I had before pretty well formulated, even without the benefit of contrast to other life styles, that the white man's burden is sterility-blandness, a world boxed in with no's and structures and hierarchies, an overdeveloped analytical facility 
which had lost the roots of body and spirit. (My friends in Tampa could articulate their psychological neuroses with the labryinthine obstruseness of a scholar, but few of them could dance.) As an undergraduate, I had been big on writers like Kazantzakis and D. H. Lawrence, but still not found a formula for a whole man.

At OEO, I watched and listened to black people. I saw a casual approach to living I didn't know about from my uptight white world; I saw laughter, a lot of clowning. They seemed to make way for fun as much as possible. This was very, very different from the all-white offices I had worked in before and during college, where everyone was watching and being watched to see that Demon Work got his due or at least put in an appearance. I flourished in this freewheeling atmosphere. Work was ever-present and sometimes overwhelming; many people worked nights and weekends and never talked about anything but OEO. But it wasn't done with the anal compulsion which makes men do busy work, get ulcers, and live in a shriveling fear that they might lose their jobs.

At OEO I got my first exposure to black people who were my intellectual equals or superiors. I was a little cowed by John Dean, then the Community Action Administrator for the Southeast. He seemed to be in perpetual amusement regarding me-perhaps stemming from our first interview, where I proclaimed "I may not look it, but I'm tough." Marie Carl, a commanding, statuesque black woman with a law degree from Yale, became my idol. I would listen to her in staff meetings and try to catch on to her extraordinary ability to go right to the heart of an issue. She had a clean, spare, forthright analytical ability which cleared away the trappings and trivia around a question, and zeroed in on it.

In my work in black communities of Florida, I discovered that the Marie Carls weren't the only ones who were my equals and betters. There was Betty Blue, a board member in the Sarasota CAP agency. At that time, she was driving a 
truck to help her husband begin a small business, raising her kids, and trying to change that large black ghetto of that small rich town, a ghetto glibly misnamed Newtown. There was Reverend John Haymon of Penney Farms, a small rural north Florida area-this time the name was appropriate. While raising ten kids, working as a janitor, preaching on Sunday, and getting himself elected as the first black man on the city council, he found time to drive fifty miles to C.AP Board meetings on nights to remind the county commissioners and other local power brokers that they were dealing with men.

I found that the Blues and the Haymons weren't unique, that from the Pompano Beach migrant camps to Pensacola, there was in every town a wealth of black people who, though they might be uneducated and poor-and usually were both-were sharp, hard-driving, and gutsy. Though it sounds maudlin, I have to say that if the Deans and the Carls cowed me, the Blues and the Haymons humbled me.

I hadn't heard about "black fever" when I lived in Atlanta, but I guess I had it. In crudest terms, this means "try black, never go back." Some white women, once they have dated black men, never date white men again. I didn't stop dating white men, but I didn't know many. I dated black men and went to black parties, where I was usually the only white present.

One night at a party I got into a heavy discussion with a male coworker. The subject was trust. He had seemed aloof and distrustful before, but I had not attributed this to race. He explained that while he liked and respected me, he would never completely trust me. I proselytized, naively, "But we're both human." He was unremittingly honest: "You're white; I'd be a fool to ever forget that." So here was the fruit of those 300 years. Well-wishing, tolerance, even submersion in the black community cannot suspend the built-in defense mechanism which conditioning has made a necessity for black people. As he explained it, the important thing was 
that we learn to coexist as reasonable human beings-little more could be expected.

Another night I sat with three black friends listening to a Nina Simone record. She was singing "Four Women." The four women-Aunt Sarah, Saffronia, Sweet Thing, Peaches-a lyrical expression of the dehumanizing and objectifying white society has done of black women. The four of us sat silent. Then another girl present, a young black student replete with Afro and African print dress, looked at me. She didn't have to say anything; her look said it all. As I perceived it, that look expressed total contempt for me. I had never felt so unmistakably indicted. I went into another room and began to cry. Suddenly I felt I bore personally the burden of white guilt. I could not forgive or forget that my ancestors had been slaveowners, that my immediate family was typically racist, that people of my color had inflicted so much pain on these other people of whom they knew so little. My friend came into the room and told me, simply, to hush.

The incidents, the scenarios during this time that came to effect a change in my consciousness are too many to relate. I went through a period, common to many whites in "the movement," of wanting to be black. Sometimes I would look at my skin, and try to figure out how even aesthetically it could be assumed superior. I seemed bleached, pale, unhealthy-looking to my own eyes. I wanted to be dusky, to have that warm coffee color of my friends. I wanted to have large black eyes, and high cheekbones, and an outrageously bush Afro. My hair was fine, my eyes blue-this absence of pigment seemed symbolic to me of an absence of a lot of things-earthiness, soul, even womanliness.

I went through changes, in short. But by the time I left OEO in 1969, I had put myself back together in my own image and was quite self-congratulatory of how well I "understood" and was "accepted by" the black community. Then my sister was raped and beaten by a black man.

As I walked toward her hospital room, every savage image, 
every fear and hatred came back to assert their primacy in my psyche. Every black I looked at, including my sister's nurse, seemed alien, dangerous, subhuman. A group of her black coworkers were standing outside her room, talking quietly, crying, and saying over and over endlessly how terrible it was. They looked at me with a kind of pleading, but even their presence seemed an affront. I walked into the room steady, but wasn't prepared for how she looked. Her head was completely swathed in bandages, her ribs taped, her arms the only part of her visible. I will never forget the sight of her arms. Her voice seemed to come from them, but her old spunk and vivacity were nowhere in the room.

When I left her, I called a friend at OEO. He met me in the waiting room, listened to me cry and wail my hate. I was afraid I could never face my black friends again. I felt that both my sister and I-in reaching out, in trusting, in trying to understand, to the bewilderment and sometime opposition of our family and friends-had been rewarded with this. I wanted to hate unremittingly. My friend told me to go ahead and feel what I was feeling, promising that it would pass.

When I saw the man who had hurt her at the pretrial hearing, I knew it was him, not black people, not blackness, and the feelings did pass. But I also knew now more profoundly what is meant by "racist." I think that all of us, black and white, are racists. We are racists in that we cannot see or deal with others without relating to color. I have had Northern white friends say with quick assurance that they "weren't raised that way." Maybe not, especially if they come from Utah or Vermont, where there are virtually no black people. Or if their father was an ACLU lawyer in New York City. My father was a mechanic from Georgia, and I have to face the fact that race is part of my way of seeing, as much as concepts of time and space. Even in being positive, attributing characteristics and behavior to race is racist. I should not generalize this to others, but I have a jaundiced view from experience in too many situations where a white 
Northern liberal, when it got to a nitty-gritty situation, had reflexes highly akin to those of his Jackson, Mississippi, brother.

I saw white failure to deal with its own racism epitomized in a kind of absurd turnabout in which a young, white, goateed bureaucrat (short on suffering and long on theory) was telling a young black man "where it's worse for blacks." The black was raised in Harlem, and was suggesting that, given Harlem or Jackson, he'd take Jackson. The white was extemporizing on the virtues of the North. Agnew's "effete snob," with the emphasis on effete, was lent unhappy substance.

\section{BEYOND OEO}

Washington, D.C., was a new dimension. For the first time, I lived "in the ghetto"-one block from the Fourteenth Street Corridor. I now had to deal with those blacks who are meant when "the people out there," "the people in the streets," "the neighborhood people," or "the folk" are discussed. The racial hostility was much more pronounced than it had been in Atlanta. Maybe this is because blacks in the North are more sophisticated, less likely to believe the promises, and therefore more apt to express their hostility. But I think it is also because Atlanta, though a Southern city, actually has more black-white interchange than Washington. Atlanta has black institutions, businesses, banks, nightclubs, and many prominent black leaders. It has been the core of the civil rights movement. Washington blacks, though they constitute over seventy percent of the city's population, are disenfranchised and dominated by a small, white, alien elite.

The hostility in Washington meant for me, on a day-to-day basis, a steady barrage of insults or propositions. I learned to steel myself to these, to assume a "cool" I felt unnatural. One day as I walked past Federal City College's physical education building, a student in a group of about ten young 
black men called out to me: "Hey, white girl! You like black boys?" I turned around, stood my ground, and yelled back: "No! I like black men." "Right on, sister" sent me on my way.

I had not remotely fathomed the hostility, however, until I spent a summer working for a black consulting group on a project which purported to take "black militants" and "white radicals" and have them evaluate HEW programs. There were 150 of us-of whom about 20 were white. The first day of training it was announced that whites weren't wanted in the program, but had to be hired because of HEW regulations. That set the tone, which got considerably heavier as training progressed. After several days of listening to my supervisor throw out phrases like "white pus," I brought up the reverse racism in a sensitivity session which was to last about four hours.

I have never been through any emotional wringing-out like that session. I went home with my first and only migraine headache. With the exception of two or three in my group, the majority black position was: we'll tolerate you, but we won't get to know you, and we sure as hell won't like you. I was on trial, with the verdict decided in advance. This, of course, had been the daily experience of these young blacks, and they took no little relish in turning the tables on me. It didn't help that being in the minority and being in the black community were not new to me-they all seemed to assume that just being near blacks was something I had never experienced and must be freaking me out. It didn't help that I wasn't 300 years old-I was held accountable for history. It didn't help that I had taken the job because I had been unemployed for three months-they assumed that any white who got into such a program was either guilt-ridden, a do-gooder, a cultural parasite, or some combination of these.

One man, in trying to tell me just how impossible communication was, said he "didn't dig on Beethoven and surfboards." I said, "Shit! Who does?" This was his percep- 
tion of young white interests. It showed me just how stereotyped are the images some blacks hold of whites. He had no idea of my concerns, my beliefs, my life style, and he wasn't interested in learning. Some in the group admitted that "hate Whitey" was an ideological necessity; they felt their first responsibility was to black people, and that helping their own required dealing with anyone white as an enemy. Let one white become humanized, and the ideology was diluted, thereby reducing their effectiveness.

I didn't accept this and I still don't. On a one-to-one, human basis, contact is always possible. It also seems to me politically unrealistic for blacks to decide not to deal with whites, to concentrate on "getting their thing together" and to let white society be damned. The building of black institutions I find both morally and politically valid, but at some point-in mundane matters like getting a bank loan, finding a publisher, renting an office-contact must be made. Total black alienation is about as realistic as deciding to boycott any product that has some capitalist taint.

Blacks who think these things can be accomplished without some kind of personalized give and take with whites, who figure they can use the white man to the black community's advantage but never recognize his humanity, are not only perpetuating hate, they are being unrealistic. Counterarguments run: "We've learned exploitation from you white folks; now we're going to use it for our own people," and "You've never shown us any great love, now don't come to us with your moralizing." One doesn't need to quote Martin Luther King to deal with this posture. To me it seems very basic to recognize that no one is willing to work very hard or do very much if in the meantime he's not going to be treated like a person.

I've been in situations where I was being told, in effect: "You've got a skill we need, but don't expect us to treat you well because you're using it in the black community." What that said to me was that they were expecting white guilt to sustain me, that I didn't merit even daily amenities. 
For two months, I worked in the program: some of my black coworkers managed not to exchange one word with me during this period. I quit in frustration, both at the bogus nature of the project itself-the establishment financing its own chastising-and at the wearing-down effect of the daily hostilities.

I told a black friend I was through with poverty programs or civil rights-related work. Blacks telling whites to get the hell out of the black community. Not wanted. Not needed. O.K. I told him no conviction compelled me to be there; I could work in a totally different setting and never feel the loss. I was angry and I was hurt-I had tried to direct my abilities and my fervor to change, and they were rejected.

He told me it wasn't as simple as that. That I could never, having known it, completely shut the black world out.

He was right. You don't pass a road sign or a leaf without having your consciousness, however imperceptibly, irremediably altered. What experiences we accrete are what we are, and we can't reject them without rejecting ourselves.

My experience of black was volatile and moving. It had cut deep.

\section{CONCLUSIONS}

What I learned and what I gained from the black world I've subsumed under the parameters of reality therapy, process, integratedness, and style.

\section{REALITY THERAPY}

It used to be possible, maybe still is for a lot of people, to live as if the black world of America didn't exist. A white suburbanite may drive through a ghetto on his way home, pay his black maid, watch a riot on $\mathrm{TV}$, and know no more of the black world. 
It's highly beneficial to learn that the black world is out there, and to know something about it on a more substantive basis than that suburbanite. This kind of learning is reality therapy in the same sense as learning a fire is burning in your basement.

Whatever a white's attitudes, it's assumed he's interested in self-preservation. Our country is now at the stage where racial interchange is a survival issue.

But by reality therapy, I mean essentially something more to do with individual coping, apart from the social-political dimensions. In brainstorming sessions with my coworkers, I've had the tendency to get lost in my own rhetoric, to theorize an issue out of sight. It has usually been blacks who have brought me down to earth. If they are interested in change for black people, bread-and-butter issues have to be foremost with them; they can't afford to breathe in that heady idealistic realm of abstraction so beloved by white intellectuals.

But the idea of bread and butter issues is really too limited a concept. The concern, the direction I'm talking about is one that takes the form of what's going to get done. Whether the "issue" concerns housing or modern dance, the black viewpoint seems to take the form of: What $x, y$, and $z$ things have to happen before A will be a reality?

Blacks seem, too, to be much more willing to accept the system as it is and to go from there. Unlike white radicals who have had what that system has to offer and are now in a position to reject it, blacks aren't primarily interested in working for that pie-in-the-sky, ideally fair social-economic system. A capitalistic economic system and a racist social structure are what confront them-they have to deal with that.

This easy assessment, of course, leaves out the Cleavers and the Angela Davises, beside whose radicalism and the sacrifices made in behalf of it, white radicalism pales. I don't make judgments on what $\mathbf{I}$ assess to be the more widely held black 
stance of an acceptance of capitalism. I simply see it as a remarkable acceptance, one that is maybe more attuned to visible, substantive progress for black people than radicalrevolutionary politicizing.

In terms of what I have personally learned from this, I guess it means something like maturation, compromise in the interests of survival. For a long time, I wouldn't accept a job that was "less than meaningful" or consider the political climate in any terms but to reject it. For, concomitant with this evolution of my black awareness, I was going through the radicalizing process common to so many young whites during the sixties. I left this country in 1969 for several months, with the thought of perhaps never coming back. To my chagrin, I learned I was an American. I came back, but I still felt hostility bordering on squeamishness for the system's political and economic processes.

It seemed too defiled for me to touch. I went the route of cultural escapism and marginal employment. To a large extent, it was exposure to my black friends' perseverance in face of that same tainted system that brought me back to it, if not with any greater acceptance, with at least a willingness to suppress the white counter-culture's affinity for failure.

There are two touchstones in the language of black reality therapy. One is "where you're coming from." You listen to the way someone talks, and what he talks about, and you learn where he's comin' from. The white approach is to ascertain "what you think" or "what you feel." "Where you're comin' from" encompasses not only what you think and what you feel, but how you got there.

The second touchstone is "dealin'." Deal is used a lot in black language: "Now that we know about this, we've got to deal with it." This is just another expression for coping behavior, but it connotes something beyond the phrase "handling a situation," maybe because we know we can handle something, without ever really dealing with it. 
PROCESS

I worked with a young black woman on the production of a report. When my job was described to me, I was told that teaching her, ensuring some transfer of skills in the process of getting out the report, was as important as the report itself. This meant I had to temper my usual goal-directed style, to curb my impatience, and to daily take into account the factors which might mean her being late or forgetting to do something. At the same time, I was not to assume her responsibilities or cover for her. This was very hard for me.

It has been much discussed how Western civilization has produced a linear, goal-directed man. This tendency, coupled with the Calvinist work ethic, produces people who are futuristic and achievement-oriented in the extreme. I am very much a product of this; in a work situation, I get hyper about things like "competence," "efficiency," "responsibility." Task completion assumes a primacy for me, often to the shutting out of the people with whom the task must be done.

Being around black people has shown me the value of process, as opposed to achievement. Blacks' process orientation is a natural result of a social milieu which made living in anything but the present somewhat foolish for them. Their past has been maligned and only recently even made known to them; their future has always been uncertain.

In a way, however, being process-oriented in the work situation with that young black woman was even more futuristic than focusing solely on the task at hand. For I knew the report was likely to go the way of most government-related documents-a file cabinet. What happened between her and me would mean more. I could give her another experience of working with a patronizing, work-compulsive white, or I could get to know her and she, me and maybe go somewhere on that long route to mutual trust and understanding. 
As it turned out, the report got done, and we got to know each other. Time was spent over coffee, talking men and cooking and race relations and a lot of other things, time whose "loss" I for the moment bemoaned. But that interchange I now see as much more important than the completion of the report.

None of this is to say that work or being responsible has to be sacrificed. Just that, no matter what we work at, we do it with people whose learning, development, and feelings are always as important as any task at hand.

\section{INTEGRATEDNESS}

"Integration" is almost never used, except to describe a social process. When I hear the word, I think not of some cookbook wholesale mixing of the races, but of the integration of the parts of one human being.

I have admired the capacity in many black people to integrate their heads with their body and their spirit. Blacks don't have a monopoly on this, but they just happen to be where I've seen it most strikingly illustrated. The earthiness of a Tina Turner, the analytical facility of a Julian Bond, and the spirit-or soul-of a Muhammed Ali I've seen in unity in individual black people.

I know black men who can play basketball, listen to the most obstruce offerings of Miles Davis, articulate political strategies, and not be out of their element in any of these situations. I know black women who are equally at home changing a diaper or the structure of a hospital board, and who meantime can wiggle a mean hip at a dance. Physical pride and machismo don't force their intellects to dormancy, nor vice versa.

We seldom relate white stereotypes-"jock," "egghead"to black men. Why is this? Perhaps society forces white people into extremes which are conducive to overdevelopment of only one aspect of the total person. Maybe it's 
because black pride is still dependent on roots and relatedness to the black community. If a black man attains status in the business or academic worlds, but loses his ability to "rap with the boys on the block," he looks the fool.

Some people believe, by an ironic twist of things, blacks will become the saviors of white society. They mean, I think, that the oppression of black people, when finally recognized and admitted, will give the white man a conscience that can then range on other human rights issues.

I think the saving aspect of blackness that whites can gain from is wholeness, totalness of being. It may be that when blacks achieve equality they, too, will lose the integratedness. Right now, it's there.

\section{STYLE}

It's been alleged that "America has no style, except for its black people." Again, such judgmental verities I can't assess. But that they do have style is incontestable.

As a teenager, I thought "culture" meant one of two things: either the artifacts of a dead civilization-as in pots and arrowheads-or that remote, esoteric, and inaccessible world of concerts, ballets, and haute couture-something that belonged to tall, thin, rich ladies.

I didn't know "culture" encompasses everything from how we wear our hair to what music we listen to. I didn't know, in short, that culture had anything to do with the living.

There is no one white culture. There are many. Unfortunately, my mind has come to judge what was my own white cultural milieu as one chiefly cluttered with products. Since I belong to no consciously "ethnic" group and was not imbued with any strong provincial ties, I find it difficult to say what $m y$ culture is. I can only conclude that it has a lot to do with shopping centers and linoleum and feminine hygiene sprays. I have a heritage-it's English, Protestant, New England, and Southern, the first three of which seem abstract to me and 
not having much relationship to my own immediate past. Culturally, I came out of middle-class plastic, with materialistic strivings overshadowing roots, race, religion, or traditions. The definable visible black culture, therefore, has much appeal to me.

My confused, ascetic college years led me to believe concern with clothes and looks was vain, more, was degenerate. Then I discovered "foxy." This is style. Not fashion, style. There is something vaguely naughty and altogether delectable about the proud sense of "foxiness."

In clothes, in music, in dance, in manners, blacks have style. Style is seen to be a bogus cloak these days, but I like it anyway. The ritualistic and the stylized can become dead ends, but this is assuming they exist in a culture without vigor. Unquestionably, black culture is hardly without vigor. It is, in fact, just beginning to fully realize itself.

The "evolution of a white's black consciousness" is not a subject which lends itself to honest expression. It seems, from the outset, a presumption. As I write this, black faces appear in my mind. Some laugh, some sneer, some go stony silent, but I know their reaction is "Yeh, tell me about it."

Because I was and am a racist, in the real meaning of the word, anything I can say about my experiences in the black world is likely to be patronizing, an odd mixture of condescending to the black man, and overidealizing him. And I know I do both.

I am guilty, as every white person is, of being a parasite of black culture. I listen to its music and ape its mannerisms.

I have, too, the standard dosage of guilt.

So all the elements are present. But I don't apologize for them any more.

All this notwithstanding, I can still say I have learned much and benefitted greatly from what the black world has given me. And I think this is very important, because the white world's long-standing assumption is that it must give and do for black people. We have talked about how black 
labor built the country, and how blacks have produced our only indigenous art form, the music of the blues and jazz. But these are abstractions not really meant to imply that individual interchange with black people is a valuable daily experience, one to be sought.

I have found that it is and an immeasurably rich one.

\section{ANNOUNCEMENT}

It is not only parents who are groping for an understanding of the new life styles of their highschool-age children. Young people themselves want to know more about why they think and behave as they do.

An indication of this is the phenomenal increase in demand for psychology courses in high schools in recent years. With more than 300,000 teenage students enrolled in psychology classes this past year (almost double the number estimated just two years ago), there is a pressing need today for teachers who have more formal grounding in the subject than "a course or two in college," as is the case with many of those handling these courses now.

To help meet this need, New York University's School of teducation is inaugurating a new graduate program this fall to prepare teachers of psychology for secondary $x$ hools. The program, under the direction of Dr. Aileen Schoeppe, Associate Professor of tducational Psychology, will lead to an M.A. degree.

The program is designed for those presently teaching the subject in high schools, as well as for psychology majors who lack teaching credentials. It aims not only to increase the teachers' own knowledge of the discipline, but to give them guidelines about "what" to teach about behavior and "how" to present it for most effective learning at this age level. Particular emphasis will be placed on giving the teacher a better understanding of the adolescent.

Further information and application, may be obtained by writing to Dr. Aileen Schoeppe, Director. Program for Teaching of Precollege Psychology, Room 933, 50 West lourth Street. New York, N.Y. 10003; or telcphoning (212) $598-2952$. 